\title{
Organic Food Consumers Purchase Patterns - Insights from Croatian Market
}

\author{
Vesna Brčić-Stipčević, Ph.D. \\ Full Professor, Faculty of Economics and Business, \\ University of Zagreb, Croatia \\ vbrcic@efzg.hr
}

Kristina Petljak, Spec.M.Sc.Econ.

Teaching and Research Assistant, Faculty of Economics and Business, University of Zagreb, Croatia kpetljak@efzg.hr

Irena Guszak, Ph.D.

Senior Teaching and Research Assistant, Faculty of Economics and Business, University of Zagreb, Croatia iguszak@efzg.hr

\section{Doi:10.5901/mjss.2013.v4n11p472}

\section{Abstract}

Organic agriculture is a holistic production system, which sustains the natural soil activity, ecosystem and people. The new system is a reaction of producers of organic food to unsustainability of capital intensive agriculture. Organic food market develops progressively because of consumers' increased interest in nutrition, health and environment protection, with the European market for organic food being the biggest market for organic food worldwide. Organic food market in Croatia is in the phase of rapid development with characteristics of mature markets. Taking into account the offer of organic food in Croatian big box retailers, the market is definitely between the growing and the developed market. Theoretical part of the paper will sum up findings about characteristics of organic food consumers and address their buying behaviour, motives for organic food purchase and perception about organic food compared to conventional food. Research results show existence of significant relationship between organic food purchase according to the region, education level, place of residence, financial status, personal monthly income and monthly household income. Further on, insights from organic food purchase patterns from Croatian market show that frequent organic food consumers consider organic food tastier and healthier than conventional, and consider that organic food with the eco-label is safer for consumption than the food without the eco-label.

Keywords: organic food, purchase patterns, empirical research, Croatia.

\section{Introduction}

The organically produced goods market grows continuously, in both food (fruits, dairy, cereals) and non-food (cosmetics, cotton) product categories. As a reaction to unsustainability of capital intensive agriculture, the producers switch to organic agriculture, the holistic production system, which sustains the natural soil activity, ecosystem and people. At the end of 2011, the organic agriculture was present in 162 countries world-wide and there were 37.2 million hectares of organic agricultural land (including in-conversion areas) (Willer, Lernoud, Home, 2013). Simultaneously, the demand side of the market is encouraged by consumers' increased, and continuously growing, interest in nutrition, health and environment protection (Gil, Gracia, Sànchez, 2000). It is estimated that organic food and drink sales reached almost 63 billion US dollars in 2011 (Willer, Lernoud, Home, 2013).

The leading organic product categories come from the food categories, and although definitions differ, many authors consider organic food as raised, grown, stored and/or processed without the use of synthetically produced chemicals or fertilisers, herbicides, pesticides, fungicides, growth hormones, regulators or genetically modified components (Brčić-Stipčević, Petljak, Guszak, 2011; Ngobo, 2011). In legal terms, a food product can only be labelled and called organic if $95 \%$ of its agricultural raw materials has been produced or grown organically. Also, it is important to 
note that all food sold as organic must come from growers, producers, processors or importers who are registered and subject to inspection.

The retail market for organic food is the biggest in Europe (Janssen, Heid, Hamm, 2009). The absolute leaders in organic food sales are Germany, United Kingdom, France and Italy, with highest market shares of organic food in the total food market in Austria (5\%), Germany, Denmark and Luxembourg (3,7 - 3,8\%) (European Commission, DirectorateGeneral for Agriculture and Rural Development, 2010), and biggest surfaces for organic production located in Italy and Spain (de Magistris, Gracia, 2008; Mesias Dìaz et al., 2012). In 2011 the total European organic market reached 21 billion Euros, which is $6 \%$ growth annually, while the organic food market was expected to grow more than the total food market (Wessanen, 2012). The organic food market was a specialist niche market, with direct selling and specialised stores as the dominant sales channels (Padel, Midmore, 2005; Brčić-Stipčević, Petljak, Guszak, 2011). However, as the demand increased, organic food market moved from the niche market towards the mainstream position. Croatian food market is one of the markets that develop rapidly. Based on the structure of organic food sales channels, Vaclavik (2009) classified Croatian organic food market as a mature market, while taking into account development and the contemporary assortment of organic food in big box retailers, it is between the growing and the developed market (Guszak, Tokić, 2012).

Whether that development will continue, depends also on the understanding of consumers' perception of organic food, their decision making process, shopping behaviour, consumers' profiles and the factors that influence the purchase of organic food. A number of studies have examined various aspects of consumers and organic food, but results are often inconsistent and generalization is still difficult. Chinnici, D'Amico, Pecorino (2002) established that diversified types of consumers exist, each of which requires specific marketing mix policies. Several authors researched the specifics of Croatian organic food consumers (Štefanić, Štefanić, Hass, 2001; Radman, 2005; First, Brozina, 2009; Cerjak et al., 2010; Brčić-Stipčević, Petljak, Guszak, 2011). Still, the existing literature does not provide sufficient information and knowledge about consumers, necessary for development of marketing strategies on this growing market.

The literature void this paper aims to fill in is identification of purchase patterns of the Croatian organic food consumers. In the literature review authors summarised previous research findings of consumers' organic food perception, consumers' characteristics, buying behaviour and motivation to buy organic food, focusing on the evidence from the Mediterranean region. Empirical part of the paper will give insights and new findings about organic food consumers in Croatia. Special emphasis is put on the exploration of purchase patterns of organic food consumers with regard to demographic and psychographic characteristics connected with organic food buying behaviour. The remainder of the paper is organised as follows. We begin with the overview of relevant literature, which is followed by the empirical research methodology. Then, we present the data analysis results. Finally, the paper ends with explanation of implications and suggestions for future research.

\section{Literature review}

One of the rare conclusions found in almost every study of organic food consumption is the overall positive attitude of consumers towards organic food. However, some consumer groups are more positive and willing to pay more for organic food, so they are the customers the marketing strategies should target (Radman, 2005). The most prominent characteristic consumers perceive of organic food is that it is healthier than conventional food (Chinnici, D'Amico, Pecorino, 2002). Although its superior taste is not widely proven, taste of organic food is rated high in Germany and United Kingdom (Fotopoulos, Krystallis, 2002). Greek consumers find organic food healthier and of higher quality than conventional food, but the higher prices are noticed too (Tsakiridou et al., 2008). Štefanić et al. (2001) reported that Croatian consumers perceived organic food as healthier, tastier and better looking than the conventional food. Based on Radman's study (2005), good quality could be added to the list, as well as the perception of organic food as rather expensive and of questionable appearance. Brčić-Stipčević, Petljak and Guszak (2011) found that for Croatian consumers three the most important organic food features are more expensive and healthier than conventional food, and organic food labelled with the organic food sign are safer than organic food without a certificate.

Consumers' motivation to buy an item highly relates to their perception, hence most consumers rank organic food's positive effects on health as their prime purchase motive. Chinnici, D'Amico, Pecorino (2002) found that in southern Italy consumers' intentions to purchase organic food are driven by health concerns (54\%) and curiosity (23\%), while de Magistris and Gracia (2008) added attitude towards environment and First and Brozina (2009) repeated healthsafety and taste as dominant organic food purchase motives in Italy. The French consumers are more concerned about environment, as Broun et al. (2009) found that their motivation for organic food box scheme lies in quality of products, 
ecological commitment and natural organic production of foods (Cerjak et al., 2010). Similarly, First and Brozina (2009) identified healthy nutrition, taste and respect for living world as dominating motives for organic food purchases in France. Care for environment and health are encouraging organic food consumption of Greek consumers (Tsakiridou et al., 2008) and same motives only in opposite order drive organic purchases on markets in Bosnia and Herzegovina, Croatia and Slovenia (Cerjak et al., 2010). According to First and Brozina (2009), Croatian consumers buy organic food because they aim to avoid harmful ingredients in food, care for own health and look for quality products, which confirm health to be a prime organic food consumption motive in Croatia.

Researchers found conflicting results on who the organic food consumers are. The particularly unclear is the role of consumers' socio-demographic characteristics. Żakowska-Biemans (2011), and Dimitri and Dettmann (2012) state that socio-demographics are not good predictors of organic purchases, or the findings are at least conflicting, but the level of education could be used to predict the likelihood to buy organic food. Higher education is an organic food consumer characteristic also found in Greece (Fotopoulos, Krystallis, 2002; Tsakiridou et al., 2008), Croatia (Brčić-Stipčević, Petljak, Guszak, 2011) and France (Ngobo, 2011). Another organic food consumer characteristic common to all markets is high income (Tsakiridou et al., 2008; Aertsens, Mondelaers, Van Huylenbroeck, 2009; Cerjak et al., 2010; BrčićStipčević, Petljak, Guszak, 2011; Ngobo, 2011). Overall, characteristics of major organic food consumers in France are high income, college education, older families and high-level occupations (Ngobo, 2011). Fotopulous and Krystallis (2002) found that Greek organic food consumers are young to middle aged, mainly women, who buy larger quantities and more frequently than men. They also found that the presence of children in family positively influences organic food purchases, while children's age is even more important (Fotopulous, Krystallis, 2002). Croatian organic food consumers are younger to middle aged, with high education and high income (Brčić-Stipčević, Petljak, Guszak, 2011), live in urban areas and women buy organic food more often than men (Radman, 2005).

Findings reported on the consumer buying behaviour are also diverse. In Bosnia and Herzegovina, Croatia and Slovenia most consumers buy organic food occasionally and mostly fresh fruit and vegetable (Cerjak et al., 2010). On Sicily, dominating organic food categories are fresh fruit and vegetables, cereals, dairy and meat (Chinnici, D'Amico, Pecorino, 2002). More available information about organic food positively influences attitudes towards organic food in southern Italy (de Magistris, Gracia, 2008). The most important sources of information about organic food are TV, newspapers and magazines (Chinnici, D'Amico, Pecorino, 2002; Renko, Bošnjak, 2009; Ranilović et al., 2008). Consumers also find important that labels guaranteeing organic production are trustworthy (Wier, Calverley, 2002). For Spanish consumers, even more than the information itself, how the information is provided influences the willingness to pay for organic food (Soler, Gil, Sànchez, 2002). The premiums consumers are willing to pay for organic food vary (Krystallis, Chryssohoidis, 2005), but the actual premium they pay often is up to $300 \%$ (Fotopulous, Krystallys, 2002). Ngobo (2011) found that French organic food consumers do not purchase organic food from concentrated categories, on average households tend to buy organic food private labels more than national brands, sales promotions negatively influence choice of organic product and quantity bought, and organic food should not be popular like any conventional brand.

Other barriers to buying organic food consumers mention include in Croatia and Greece high prices and deficiencies in distribution (Radman, 2005; Tsakiridou et al., 2008), in Spain insufficient knowledge about organic food, high price premiums and difficulty to develop new trading channels (Mesias Dìaz et al., 2012), in Poland issue of trust in organic food and credibility of certification system (Żakowska-Biemans, 2011) and in Italy high cost of organic food certification, which hinder organic farms to sell their products with certificates (de Magistris, Gracia, 2008).

\section{Empirical research}

\subsection{Research sample and research instrument}

Empirical research on the organic food purchase patterns from the Croatian market was carried out in March 2009, through face-to-face interviews in households, on a sample of Croatian citizens older than 15 years. Sources of the data for defining the framework for a sample selection were the results of the census conducted in 2001 by the Croatian Bureau of Statistics. The stratification was two-dimensional and was conducted according to 6 traditional regions defined as a set of existing counties ${ }^{1}$ and according to 4 settlement sizes ${ }^{2}$. For survey dissemination, professional market

1 Zagreb and surroundings (includes Zagreb county and the City of Zagreb), Northern Croatia (includes Krapinsko-zagorska county, Varaždinska county, Koprivničko-križevačka county, Bjelovarsko-bilogorska county, Virovitičko-podravska county and Međimurska county), region Slavonia (includes Požeško-slavonska county, Brodsko-posavska county, Osječko-baranjska county and Vukovarsko- 
research agency's network of field operatives was used. The research instrument was a highly structured questionnaire.

\subsection{The respondents' characteristics}

The research was conducted on a representative sample of 1.000 respondents (study included 471 men and 529 females). The age range of respondents was from 15 to 86 years and they were equally represented in all age categories (18-24, 25-34, 35-44, 45-54, 55-64 and older than 65), except in the youngest age category (15-17), in which there were at least respondents.

Research covered the territory of the Republic of Croatia, majority of respondents were from Zagreb and surroundings (24.9\%), followed by Dalmatia (19.0\%), Northern Croatia (18.0\%), Slavonia (17.4\%), Istra, Primorje and Gorski kotar (11.9\%) and Lika, Kordun and Banovina (8.8\%).

According to the settlement size, most of the respondents were from settlement up to 2.000 inhabitants (40.1\%), least from a settlement between 2.001 and 10.000 inhabitants (15.3\%), while the settlement between 10.001 and 100.000 inhabitants and over 100.000 inhabitants were evenly represented (21.2\% and 23.5\%).

Regarding the marital status of research participants, most (53.1\%) were married. There was $29.7 \%$ unmarried or singles, and a small proportion (17.2\%) of widowers, widows and divorced respondents.

The most sample respondents had a high school diploma (63.8\%), 16.3\% finished elementary education, while college or higher education finished $13.6 \%$ respondents. The smallest proportion of participants (6.3\%) was without completed elementary school.

One half of participants (51.3\%) were unemployed, 38.4\% were employed and proportions of other employment categories (fixed-term contracts, part-time, self-employed, not registered) were only minor.

Most research respondents were retired (27.4\%), 16.7\% were qualified workers, $15.2 \%$ clerks, and $10.0 \%$ pupils. Other occupation categories (housewives, entrepreneurs, low and middle management) were only minor in the sample structure.

Most respondents were individuals in charge of the household (44.2\%), 34.9\% of respondents were the 'head of the family', while $20.9 \%$ were other family/household members. Further on, most households had two members (27.8\%), 3-member households were represented with $22.4 \%$, and 4-members and single households were equally represented, with $19.5 \%$ and $19.2 \%$ respectively. The smallest number of households in the sample was with five and more members (11.1\%).

In $69.1 \%$ of households, there was no children under 18 years of age in, kids younger than six years were found in $12.7 \%$ of households, kids between seven and fourteen lived in $15.6 \%$ of households and $10.2 \%$ of households had teenagers between 15 and 18 years.

Vast majority of respondents (65.0\%) live in houses, while others live in apartment buildings.

Regarding financial status, $67.3 \%$ research respondents found their financial status as the average one, followed by respondents who found their financial status to be somewhat below average (14.9\%) and those who found it much below average $(9.0 \%), 8.0 \%$ of respondents found it somewhat better than average and only $0.8 \%$ said it was much better than average.

For most participants (90.7\%) income comes from the non-agricultural activities, while $8.3 \%$ respondents combines agriculture and other activities as their income sources and only 1.1\% lives of agriculture.

Across research sample, personal monthly income varies greatly. Research results indicate that $17.3 \%$ of research respondents had no source of income, while $11.9 \%$ did not answer. From the remaining respondents, the most frequent income category was $2.001-3.500 \mathrm{HRK}(30.4 \%)$, then the $3.501-5.500 \mathrm{HRK}$ range $(27.8 \%), 1.201-2.000$ HRK (20.1\%), under 1.200 HRK (10.3\%), $5.501-7.000$ HRK (7.2\%) and the least frequent categories were $7.001-$ 9.000 HRK (2.2\%) and over 9.000 HRK (2.1\%).

Monthly household income was not stated by $22.2 \%$ respondents. Among others, answers were equally distributed in $5.501-8.000$ HRK (22\%) and $1.801-3.500$ HRK (21.8\%) categories. They are followed by categories $3.501-5.500$ HRK (17.6\%) and $8.001-11.000$ HRK (17.3\%), up to 1.800 HRK (10\%), and finally, category over 11.000 HRK (11.4\%).

srijemska county); region Lika, Kordun and Banovina (includes Sisačko-moslavačka county, Karlovačka county and Ličko-senjska county), region Istra, Primorje and Gorski kotar includes Primorsko-goranska county and Istarska county, and region Dalmatia includes Zadarsko-kninska county, Šibenska county, Splitsko-dalmatinska county and Dubrovačko-neretvanska county.

2 up to 2.000 inhabitants; from 2.001 to 10.000 inhabitants; from 10.001 to 100.000 inhabitants and over 100.000 inhabitants. 


\subsection{Organic food purchase patterns according to socio-demographic characteristics of respondents}

The following segments are dedicated to the organic food purchase patterns, controlled for the socio-demographic characteristics of the sample: 1) gender, 2) age, 3) region, 4) settlement size, 5) marital status, 6) educational level, 7) employment status, 8) household status, 9) number of household members, 10) place of residence, 11) financial status, 12) belonging to financial class, 13) source of income, 14) personal monthly income and 15) monthly household income. After conducting statistical data analysis, research results will be elaborated and explained hereafter.

According to the research conducted on Croatian market, no statistically significant difference by gender in the organic food purchase was found $\left(\chi^{2}=2.006, p>0.05\right)$. Further on, although literature suggests possible differences in organic food purchase according to the age, research results showed that no statistically significant difference by age in the organic food purchase was found $\left(\chi^{2}=17.594, p>0.05\right)$.

Table 1. Organic food purchase by region

\begin{tabular}{|c|c|c|c|c|c|c|c|c|c|c|c|c|}
\hline \multirow{3}{*}{$\begin{array}{c}\text { organic food } \\
\text { purchase }\end{array}$} & \multicolumn{12}{|c|}{ region } \\
\hline & \multicolumn{2}{|c|}{$\begin{array}{l}\text { Zagreb and } \\
\text { surroundings }\end{array}$} & \multicolumn{2}{|c|}{$\begin{array}{l}\text { Northern } \\
\text { Croatia }\end{array}$} & \multicolumn{2}{|c|}{ Slavonia } & \multicolumn{2}{|c|}{$\begin{array}{l}\text { Lika, Kordun } \\
\text { and Banovina }\end{array}$} & \multicolumn{2}{|c|}{$\begin{array}{l}\text { Istra, Primorje } \\
\text { and Gorski kotar }\end{array}$} & \multicolumn{2}{|c|}{ Dalmatia } \\
\hline & $f$ & $\%$ & f & $\%$ & $f$ & $\%$ & $f$ & $\%$ & $f$ & $\%$ & $f$ & $\%$ \\
\hline never & 73 & 39.5 & 86 & 55.1 & 82 & 65.1 & 28 & 39.4 & 46 & 49.5 & 70 & 50.7 \\
\hline rarely & 83 & 44.9 & 59 & 37.8 & 37 & 29.4 & 28 & 39.4 & 29 & 31.2 & 53 & 38.4 \\
\hline often & 29 & 15.7 & 11 & 7.1 & 7 & 5.6 & 15 & 21.1 & 18 & 19.4 & 15 & 10.9 \\
\hline$\chi^{2}, p$ & & & & & & $\chi^{2}=$ & $06 ;$ & & & & & \\
\hline
\end{tabular}

There is a statistically significant difference in the purchase of organic food according to the region $\left(\chi^{2}=36.506 ; p<0.01\right)$. Organic food is often bought by the highest percentage of respondents in Lika, Kordun and Banovina (21.1\%), and lowest percentage of respondents in the Slavonia (5.6\%). Organic food is rarely bought by the highest percentage of respondents in the Zagreb and surroundings (44.9\%), and lowest percentage of respondents in Slavonia (29.4\%). Organic food is never bought by the highest percentage of respondents from Slavonia (65.1\%), and the smallest percentage of respondents in Lika, Kordun and Banovina (39.4\%).

Statistical analysis was also done according to the organic food purchase by settlement size and marital status, where no statistically significant difference was found for the purchase of organic food by settlement size $\left(\chi^{2}=8.674\right.$, $p>0.05)$ nor by marital status $\left(\chi^{2}=2.693, p>0.05\right)$.

Table 2. Organic food purchase by education level

\begin{tabular}{|c|c|c|c|c|c|c|c|c|c|c|}
\hline \multirow{3}{*}{$\begin{array}{c}\text { organic food } \\
\text { purchase }\end{array}$} & \multicolumn{10}{|c|}{ education level } \\
\hline & \multicolumn{2}{|c|}{$\begin{array}{c}\text { no elementary } \\
\text { school }\end{array}$} & \multicolumn{2}{|c|}{$\begin{array}{c}\text { elementary } \\
\text { school }\end{array}$} & \multicolumn{2}{|c|}{$\begin{array}{c}\text { high school (3 } \\
\text { years) }\end{array}$} & \multicolumn{2}{|c|}{$\begin{array}{c}\text { high school (4 } \\
\text { years) }\end{array}$} & \multicolumn{2}{|c|}{$\begin{array}{l}\text { college or higher } \\
\text { education }\end{array}$} \\
\hline & $f$ & $\%$ & $f$ & $\%$ & $f$ & $\%$ & $f$ & $\%$ & $f$ & $\%$ \\
\hline never & 20 & 55.6 & 69 & 65.7 & 94 & 59.5 & 165 & 47.4 & 38 & 30.9 \\
\hline rarely & 10 & 27.8 & 25 & 23.8 & 50 & 31.6 & 142 & 40.8 & 61 & 49.6 \\
\hline often & 6 & 16.7 & 11 & 10.5 & 14 & 8.9 & 41 & 11.8 & 24 & 19.5 \\
\hline$\chi^{2}, p$ & & & & & $2=3$ & $; p$ & & & & \\
\hline
\end{tabular}

Research results analysis found statistically significant difference in the purchase of organic food by education level of respondent $\left(\chi^{2}=38.615, p<0.01\right)$. Organic food is often in the largest percentage bought by respondents who completed college or university $(19.5 \%)$, what is in alignment with literature and in the lowest percentage by respondents who have completed three years high school (8.9\%). Organic food is rarely in the largest percentage bought by respondents who completed college or university $(49.6 \%)$, and in the smallest percentage by respondents with no educational qualifications (27.8\%). Organic food is never bought by the largest percentage of respondents with no educational qualifications (55.6\%), and by the smallest percentage of respondents who have completed college or university (30.9\%).

Further on, no statistically significant difference in the purchase of organic food by employment status $\left(\chi^{2}=17.053\right.$, $p>0.05)$, household status $\left(\chi^{2}=5.018, p>0.05\right)$ and number of household members $\left(\chi^{2}=10.775, p>0.05\right)$ was found. 
Table 3. Organic food purchase by place of residence

\begin{tabular}{|c|c|c|c|c|}
\hline & \multicolumn{4}{|c|}{ place of residence } \\
\hline \multirow{2}{*}{ organic food purchase } & \multicolumn{2}{|c|}{ house } & apartment in the building \\
\cline { 2 - 5 } & $\mathrm{f}$ & $\%$ & $\mathrm{f}$ & $\%$ \\
\hline never & 276 & 54.8 & 109 & 41.3 \\
\hline rarely & 175 & 34.7 & 113 & 42.8 \\
\hline often & 53 & 10.5 & 42 & 15.9 \\
\hline$\chi^{2}, \mathbf{p}$ & \multicolumn{5}{|c|}{$\chi^{2}=13.365 ; \mathbf{p}<0.01$} \\
\hline
\end{tabular}

Statistically significant difference in the purchase of organic food by the place of residence was found $\left(\chi^{2}=13.365\right.$, $p<0.01)$. Organic food is in a higher percentage often bought by respondents who live in apartments in the building (15.9\%), compared to those who live in houses (10.5\%). Organic food is in a higher percentage rarely bought by respondents who live in apartments in the building (42.8\%) compared to those who live in houses (34.7\%). Organic food is in a higher percentage never bought by respondents who live in houses (54.8\%), compared to respondents who live in apartments in the building (41.3\%).

Table 4. Organic food purchase by financial status

\begin{tabular}{|c|c|c|c|c|c|c|c|c|c|c|}
\hline \multirow{3}{*}{$\begin{array}{c}\text { organic food } \\
\text { purchase }\end{array}$} & \multicolumn{10}{|c|}{ financial status } \\
\hline & \multicolumn{2}{|c|}{$\begin{array}{l}\text { much worse } \\
\text { than average }\end{array}$} & \multicolumn{2}{|c|}{$\begin{array}{c}\text { slightly below } \\
\text { average }\end{array}$} & \multicolumn{2}{|c|}{$\begin{array}{c}\text { average, like } \\
\text { majority }\end{array}$} & \multicolumn{2}{|c|}{$\begin{array}{l}\text { slightly better } \\
\text { than average }\end{array}$} & \multicolumn{2}{|c|}{$\begin{array}{l}\text { much better } \\
\text { than average }\end{array}$} \\
\hline & $f$ & $\%$ & $f$ & $\%$ & $f$ & $\%$ & $f$ & $\%$ & $f$ & $\%$ \\
\hline never & 48 & 77.4 & 48 & 46.2 & 264 & 50.2 & 22 & 31.9 & 3 & 42.9 \\
\hline rarely & 8 & 12.9 & 43 & 41.3 & 202 & 38.4 & 34 & 49.3 & 1 & 14.3 \\
\hline often & 6 & 9.7 & 13 & 12.5 & 60 & 11.4 & 13 & 18.8 & 3 & 42.9 \\
\hline$\chi^{2}, p$ & & & & & $=36$ & $\mathrm{p}<$ & & & & \\
\hline
\end{tabular}

Statistically significant difference in the purchase of organic food according to the perceived financial status of respondent was found $\left(\chi^{2}=36.634, p<0.01\right)$. Organic food is often bought by the largest percentage of respondents who perceive that their financial status is much better than average (42.9\%), and by the smallest percentage of respondents who perceive their financial status is much worse than the average (9.7\%). Organic food is rarely bought by the largest percentage of respondents who perceive their financial status is slightly better than average (49.3\%), and by the smallest percentage of respondents who perceive their financial status is much worse than the average (12.9\%). Organic food is never bought by the largest percentage of those respondents who consider their financial status is much worse than the average (77.4\%) and it is in the least extent bought by respondents whose financial status is slightly better than average (31.9\%).

Surprisingly, no statistically significant difference by source of income in the purchase of organic food was found $\left(\chi^{2}=2.558, p>0.05\right)$.

Table 5. Organic food purchase by personal monthly income

\begin{tabular}{|c|c|c|c|c|c|c|c|c|c|c|c|c|c|c|}
\hline \multirow{3}{*}{$\begin{array}{l}\text { organic food } \\
\text { purchase }\end{array}$} & \multicolumn{14}{|c|}{ personal monthly income } \\
\hline & \multicolumn{2}{|c|}{$\begin{array}{c}\text { up to } 1.200 \\
\text { HRK }\end{array}$} & \multicolumn{2}{|c|}{$\begin{array}{c}1.201-2.000 \\
H R K\end{array}$} & \multicolumn{2}{|c|}{$\begin{array}{c}2.001-3.500 \\
H R K\end{array}$} & \multicolumn{2}{|c|}{$\begin{array}{c}3.501-5.500 \\
\text { HRK }\end{array}$} & \multicolumn{2}{|c|}{$\begin{array}{c}5.501-7.000 \\
H R K\end{array}$} & \multicolumn{2}{|c|}{$\begin{array}{c}\text { 7.001-9.000 } \\
\text { HRK }\end{array}$} & \multicolumn{2}{|c|}{$\begin{array}{c}\text { over } 9.000 \\
\text { HRK }\end{array}$} \\
\hline & $f$ & $\%$ & $f$ & $\%$ & f & $\%$ & $f$ & $\%$ & $f$ & $\%$ & $f$ & $\%$ & $f$ & $\%$ \\
\hline never & 28 & 57.1 & 50 & 54.9 & 94 & 55.0 & 67 & 40.9 & 10 & 24.4 & 5 & 31.3 & 4 & 28.6 \\
\hline rarely & 18 & 36.7 & 30 & 33.0 & 63 & 36.8 & 78 & 47.6 & 21 & 51.2 & 9 & 56.3 & 5 & 35.7 \\
\hline often & 3 & 6.1 & 11 & 12.1 & \begin{tabular}{|l|}
14 \\
\end{tabular} & 8.2 & 19 & 11.6 & 10 & 24.4 & 2 & 12.5 & 5 & 35.7 \\
\hline$\chi^{2}, p$ & & & & & & & & & & & & & & \\
\hline
\end{tabular}

By conducting research results analysis we found a statistically significant difference in the purchase of organic food according to the personal monthly income $\left(\chi^{2}=33.947, p<0.01\right)$. Organic food is often bought by the largest percentage of respondents with personal monthly income over 9.000 HRK (35.7\%), and smallest percentage of respondents with a 
personal monthly income up to 1.200 HRK $(6.1 \%)$. Organic food is rarely bought by the largest percentage of respondents with personal monthly income between 7.001 and 9.000 HRK (56.3\%), and by the smallest percentage of respondents with personal monthly income between 1.201 and 2.000 HRK (33.0\%). Organic food is in the highest percentage never bought by respondents with personal monthly income up to 1.200 HRK (57.1\%), what is expected and by lowest percentage of respondents with a personal monthly income between 5.501 and 7.000 HRK (24.4\%).

Table 6. Organic food purchase by monthly household income

\begin{tabular}{|c|c|c|c|c|c|c|c|c|c|c|c|c|}
\hline \multirow{3}{*}{$\begin{array}{l}\text { organic food } \\
\text { purchase }\end{array}$} & \multicolumn{12}{|c|}{ monthly household income } \\
\hline & \multicolumn{2}{|c|}{$\begin{array}{c}\text { up to } 1.800 \\
\text { HRK }\end{array}$} & \multicolumn{2}{|c|}{$\begin{array}{c}1.801-3.500 \\
H R K\end{array}$} & \multicolumn{2}{|c|}{$\begin{array}{c}3.501-5.500 \\
\text { HRK }\end{array}$} & \multicolumn{2}{|c|}{$\begin{array}{c}5.501-8.000 \\
\text { HRK }\end{array}$} & \multicolumn{2}{|c|}{$\begin{array}{c}8.001-11.000 \\
\text { HRK }\end{array}$} & \multicolumn{2}{|c|}{$\begin{array}{l}\text { over } 11.000 \\
\text { HRK }\end{array}$} \\
\hline & $f$ & $\%$ & $f$ & $\%$ & f & $\%$ & $f$ & $\%$ & $f$ & $\%$ & $f$ & $\%$ \\
\hline never & 29 & 59.2 & 64 & 54.7 & 65 & 58.0 & 60 & 46.2 & 36 & 33.6 & 32 & 41.6 \\
\hline rarely & 15 & 30.6 & 39 & 33.3 & 35 & 31.3 & 59 & 45.4 & 57 & 53.3 & 35 & 45.5 \\
\hline often & 5 & 10.2 & 14 & 12.0 & 12 & 10.7 & 11 & 8.5 & 14 & 13.1 & 10 & 13.0 \\
\hline$\chi^{2}, p$ & & & & & $=22$ & $\mathrm{p}<0$ & & & & & & \\
\hline
\end{tabular}

Statistically significant difference was found in the purchase of organic food according to the level of monthly household income $\left(\chi^{2}=22.123, p<0.05\right)$. Organic food is often purchased by the largest percentage of respondents whose monthly household income is between 8.001 and 11.000 HRK (13.1\%) and respondents with monthly household income over 11.000 HRK (13.0\%), whereas it is often purchased by the smallest percentage of respondents with a household income between 5.501 and 8.000 HRK (8.5\%). Organic food is rarely bought by the largest percentage of respondents whose household monthly income is between 8.001 and $11.000 \mathrm{HRK}(53.3 \%)$, and it is rarely bought by the smallest percentage of respondents with a household income up to 1.800 HRK per month (30.6\%). Organic food is never bought by the highest percentage of respondents with a household income up to $1.800 \mathrm{HRK}(59.2 \%)$, and lowest percentage of respondents whose monthly household income is between 8.001 and $11.000 \mathrm{HRK}(33.6 \%)$.

\subsection{Organic food purchase patterns according to the perception of organic food compared to conventional food}

Further on, empirical research investigated respondents' organic food purchase patterns according to the perception of organic food in relation to conventional food. Respondents' perception of organic food compared to conventional food was examined using the five-point Likert scale, where 1 represented complete disagreement and 5 complete agreement with the statement. In order to determine whether there are differences in the comparison of organic food and conventional food according to the organic food purchase, analysis of variance was carried out. Further on, among differences that proved to be statistically significant, Scheffe post-hoc test was conducted.

Table 7. Organic food purchase according to the perception of organic food compared to conventional food

\begin{tabular}{|c|c|c|c|c|c|c|c|c|}
\hline \multirow{3}{*}{ statement } & \multicolumn{6}{|c|}{ organic food purchase } & \multirow{3}{*}{$\mathbf{F}$} & \multirow{3}{*}{$\mathrm{p}$} \\
\hline & \multicolumn{2}{|c|}{ never } & \multicolumn{2}{|c|}{ rarely } & \multicolumn{2}{|c|}{ often } & & \\
\hline & M & SD & M & SD & M & SD & & \\
\hline $\begin{array}{l}\text { Conventional food is the food without } \\
\text { the 'organic origin' label. }\end{array}$ & 3.40 & 1.128 & 3.46 & 1.145 & 3.55 & 1.219 & 0.72 & 0.486 \\
\hline $\begin{array}{l}\text { Organic food is tastier than } \\
\text { conventional food. }\end{array}$ & 3.00 & 1.139 & 3.38 & 1.129 & 3.89 & 1.185 & 25.79 & 0.000 \\
\hline $\begin{array}{l}\text { Organic food is more expensive than } \\
\text { conventional food. }\end{array}$ & 4.24 & 0.937 & 4.24 & 0.947 & 4.27 & 0.931 & 0.04 & 0.960 \\
\hline $\begin{array}{l}\text { Organic food is healthier for me and } \\
\text { my family than conventional food. }\end{array}$ & 3.63 & 1.040 & 4.23 & 0.811 & 4.33 & 0.893 & 42.80 & 0.000 \\
\hline $\begin{array}{l}\text { Organic food with the eco-label is } \\
\text { safer for consumption than the food } \\
\text { without it. }\end{array}$ & 3.44 & 1.038 & 3.70 & 0.958 & 3.78 & 1.107 & 7.90 & 0.000 \\
\hline
\end{tabular}

$\mathrm{M}$ - mean, SD - standard deviation

Research analysis found no statistically significant difference in the response to the statement 'Conventional food is the 
food without the 'organic origin' label.' $(\mathrm{F}=0.72, \mathrm{p}>0.05)$. However, we found statistically significant difference in the response to the statement 'Organic food is tastier than conventional food.' according to the organic food purchase $(F=$ $25.79, p<0.01$ ). Respondents who state that they never buy organic food to a lesser extent believe that organic food is tastier than conventional food with regard to respondents who rarely buy organic food and respondents who often buy organic food. Also, respondents who rarely buy organic food to a lesser extent believe that organic food is tastier than conventional food, when compared to respondents who often buy organic food.

No statistically significant difference in the response to the statement 'Organic food is more expensive than conventional food.' considering organic food purchase was found ( $F=0.04, p>0.05)$.

Statistically significant difference in the response to the statement 'Organic food is healthier for me and my family than conventional food.' according to organic food purchase was found ( $F=42.80, p<0.01)$. Respondents who never buy organic food to a lesser extent believe that organic food is healthier for them and their families from the conventional food than respondents that rarely and often buy organic food.

Statistically significant difference in the response to the statement 'Organic food with the eco-label is safer for consumption than the food without it.' according to the organic food purchase was found ( $F=7.90, p<0.01)$. Respondents who never buy organic food to a lesser extent believe that organic food marked with eco-label is safer for consumption than organic food without eco-label, than respondents who buy organic food rarely and often.

\section{Conclusion}

The paper gives the insight into organic food consumers purchase patterns based on literature review and empirical research conducted on Croatian market. Research results indicate significant connections in organic food purchase according to the region, education level, place of residence, financial status, personal monthly income and monthly household income. Research results indicate that Croatian consumers find organic food tastier and healthier than conventional. Also, they consider that organic food with the eco-label is safer for consumption than the food without the eco-label. Future research should aim at more detailed identification of a profile of Croatian organic food consumers. The original contribution of this research is in the detailed insight into organic food purchase patterns from Croatian market, from the perspective of frequent, rare and non-buyers of organic food. Research results yield new knowledge about organic food consumers and their purchase patterns, and can be useful for further stimulation of organic food consumption and organic food market development in Croatia.

\section{References}

Aertsens, J., Mondelaers, K., \& Van Huylenbroeck, G. (2009). Differences in retail strategies on the emerging organic market. British Food Journal, 111 (2), 138-154.

Brčić-Stipčević, V., Petljak, K., \& Guszak, I. (2011). Empirical research of attitudes towards organic food among Croatian consumers. In Rakitovac Afrić, K., Šugar, V., Bevanda, V. (Eds.) Conference proceedings of the 5th International Scientific Conference 'Entrepreneurship and Macroeconomic Management: Reflections on the World in Turmoil', Volume 2, Sveučilište Jurja Dobrile u Puli, Odjel za ekonomiju i turizam 'Dr. Mijo Mirković', 1376-1405.

Cerjak, M., Mesić, Ž., Kopić, M., Kovačić, D. \& Markovina, J. (2010). What motivates consumers to buy organic food: Comparison of Croatia, Bosnia Herzegovina, and Slovenia. Journal of Food Products Marketing, 16 (3), 278-292.

Chinnici, G., D'Amico, M., \& Pecorino, B. (2002). A multivariate statistical analysis of the consumers of organic products. British Food Journal, 104 (3/4/5), 187-199.

De Magistris, T. \& Gracia, A. (2008). The decision to buy organic food products in Southern Italy. British Food Journal, 110 (9), 929-947.

Dimitri, C. \& Dettmann, R. L. (2012). Organic food consumers: what do we really know about them ?. British Food Journal, 114 (8), $1157-1183$

European Commission, Directorate-General for Agriculture and Rural Development (2010). An analysis of the EU organic sector, [Online] Available: http://ec.europa.eu/agriculture/analysis/markets/organic_2010_en.pdf (May 17, 2012)

First, I. \& Brozina, S. (2009). Cultural influences on motives for organic food consumption. EuroMed Journal of Business, 4 (2), 185-199.

Fotopoulos, C. \& Krystallis, A. (2002). Purchasing motives and profile of the Greek organic consumer: a countrywide survey. British Food Journal, 104 (9), 730-765.

Gil, J. M., Gracia, A., \& Sànchez, M. (2000). Market segmentation and willingness to pay for organic products in Spain. The International Food and Agribusiness management Review, 3 (2), 207-226.

Guszak, I. \& Tokić, B. (2012). Doprinos maloprodavača održivom razvoju primjenom trgovačkih marki. In Knego, N., Renko, S., Knežević, B. (Eds.), Perspektive trgovine 2012.: Trgovina u kontekstu održivog razvoja (227-249). Zagreb, Ekonomski fakultet Sveučilišta u Zagrebu.

Janssen, M., Heid, A., \& Hamm, U. (2009). Is there a promising market 'in between' organic and conventional food? Analysis of 
consumer preferences. Renewable Agriculture and Food Systems, 24 (3), 205-213.

Krystallis, A. \& Chryssohoidis, G. (2005). Consumers' willingness to pay for organic food. British Food Journal, 107 (5), $320-343$.

Mesias Dìaz, F. J., Martìnez-Carrasco Pleite, F., Mart̀nez Paz, J. M. \& Gaspar Garcìa, P. (2012). Consumer knowledge, consumption, and willingness to pay for organic tomatoes. British Food Journal, 114 (3), 318-334.

Ngobo, P. V. (2011). What Drives Household Choice of Organic Products in Grocery Stores? Journal of Retailing, 87 (1), $90-100$.

Padel, S. \& Midmore, A. (2005). The development of the European market for organic products: insights from a Delphi study. British Food Journal, 107 (8), 626-647.

Radman, M. (2005). Consumer consumption and perception of organic products in Croatia. British Food Journal, 107 (4), $263-273$.

Ranilović, J., Markovina, J., Žnidar, K. \& Colić Barić, I. (2008). Attitudes to healthy eating among a representative sampling of Croatian adults: A comparison with Mediterranean countries. International Journal of Food Sciences and Nutrition, 60 (7), 1-19.

Renko, S. \& Bošnjak, K. (2009). Aktualno stanje i perspektive budućeg razvoja tržišta ekološke hrane u Hrvatskoj. Ekonomski pregled, 60 (7-8), 369-395.

Soler, F. Gil, J. M., \& Sànchez. M. (2002). Consumers' acceptability of organic food in Spain. British Food Journal, 104 (8), $670-687$.

Štefanić, I., Štefanić, E., \& Haas, R. (2001). What the consumer really wants: organic food market in Croatia. Die Bodenkultur, 52 (4), 323-328.

Tsakiridou, E., Boutsouki, C., Zotos, Y. \& Mattas, M. (2008). Attitudes and behaviour towards organic products: an exploratory study. International Journal of Retail \& Distribution Management, 36 (2), 158-175.

Vaclavik, T. (2009). Specialised Organic Retail Report Europe 2008, Organic Eprints, [Online] Available: http://orgprints.org/15482/03/vaclavic-2009-cee.pdf, (February 26, 2013)

Wessanen (2012). Market review organic food, [Online] Available: http://www.wessanen.com/en/about-wessanen/market-review/ (September 18, 2012)

Wier, M. \& Calverley, C. (2002). Market potential for organic food in Europe. British Food Journal, 104 (1), 45-62.

Willer, H., Lernoud, J., \& Home, R. (2013). The World of Organic Agriculture 2013: Summary, [Online] Available: http://www.organicworld.net/fileadmin/documents/yearbook/2013/web-fibl-ifoam-2013-25-34.pdf, (June 28, 2013)

Żakowska-Biemans, S. (2011). Polish consumer food choices and beliefs about organic food. British Food Journal, 113 (1), $122-137$. 